\begin{tabular}{|c|c|c|c|c|c|c|}
\hline \multirow{3}{*}{$\begin{array}{l}\text { 2. ECN Category } \\
\text { (mark one) } \\
\\
\text { Supplemental } \\
\text { Direct Revision } \\
\text { Change ECN } \\
\text { Temporary } \\
\text { Standby } \\
\text { Supersedure } \\
\text { Cancel/Noid }\end{array}$} & \multirow{3}{*}{$\begin{array}{r}{[]} \\
{[X]} \\
{[]} \\
{[]} \\
0] \\
{[]} \\
{[0}\end{array}$} & \multicolumn{2}{|c|}{$\begin{array}{l}\text { 3. Originator's Name, Organization, MSIN, } \\
\text { and Telephone No. } \\
\text { Clarence Homi. Data Assessment } \\
\text { and Interpretation. R2-12. 373- } \\
1097\end{array}$} & \multicolumn{2}{|c|}{$\begin{array}{l}\text { 3a. USO Required? } \\
{[] \text { Yes }[X] \text { No }}\end{array}$} & $\begin{array}{l}\text { 4. Date } \\
05 / 07 / 96\end{array}$ \\
\hline & & \multicolumn{2}{|c|}{$\begin{array}{l}\text { 5. Project Title/No./Work Order No. } \\
\text { Tank } 241-A-104\end{array}$} & \multicolumn{2}{|c|}{$\begin{array}{l}\text { 6. Bldg./Sys./Fac. No. } \\
241-A-104\end{array}$} & $\begin{array}{l}\text { 7. Approval Designator } \\
N / A\end{array}$ \\
\hline & & \multicolumn{2}{|c|}{$\begin{array}{l}\text { 8. Document Numbers Changed by this ECN } \\
\text { (includes sheet no. and rev.) } \\
\text { WHC-SD-WM-TP-247, Rev. O-A }\end{array}$} & \multicolumn{2}{|c|}{$\begin{array}{l}\text { 9. Related ECN No(s). } \\
\text { ECN-617813 }\end{array}$} & $\begin{array}{l}\text { 10. Related PO No. } \\
\text { N/A }\end{array}$ \\
\hline \multirow{2}{*}{\multicolumn{2}{|c|}{$\begin{array}{l}\text { 11a. Modification Work } \\
\text { [] Yes (fill out Blk. } \\
11 \mathrm{~b}) \\
{[X] \text { No (NA Blks. 11b, }} \\
11 c, 11 \mathrm{~d})\end{array}$}} & \multirow[t]{2}{*}{$\begin{array}{l}\text { 11b. Work Package } \\
\text { No. } \\
\text { N/A }\end{array}$} & \multirow{2}{*}{\multicolumn{2}{|c|}{$\begin{array}{l}\text { 11c. Modification Work Complete } \\
\text { N/A } \\
\text { Cog. Engineer Signature \& Date }\end{array}$}} & \multicolumn{2}{|c|}{$\begin{array}{l}\text { 11d. Restored to Original Condi- } \\
\text { tion (Temp. or Standby ECN only) } \\
\text { N/A }\end{array}$} \\
\hline & & & & & Cog. En & neer Signature \& Date \\
\hline
\end{tabular}

12. Description of change

Complete revision.

13a. Justification (mark one)

$\begin{array}{llll}\text { Criteria Change } & {[X]} & \text { Design Improvement } \\ \text { As-Found } & {[]} & \text { Facilitate Const }\end{array}$

13b. Justification Details

Changed to comply with new template and DOE-RL recommended modifications.

14. Distribution (include name, MSIN, and no. of copies)

See attached distribution. 
Page 2 of 2

ECN-631543

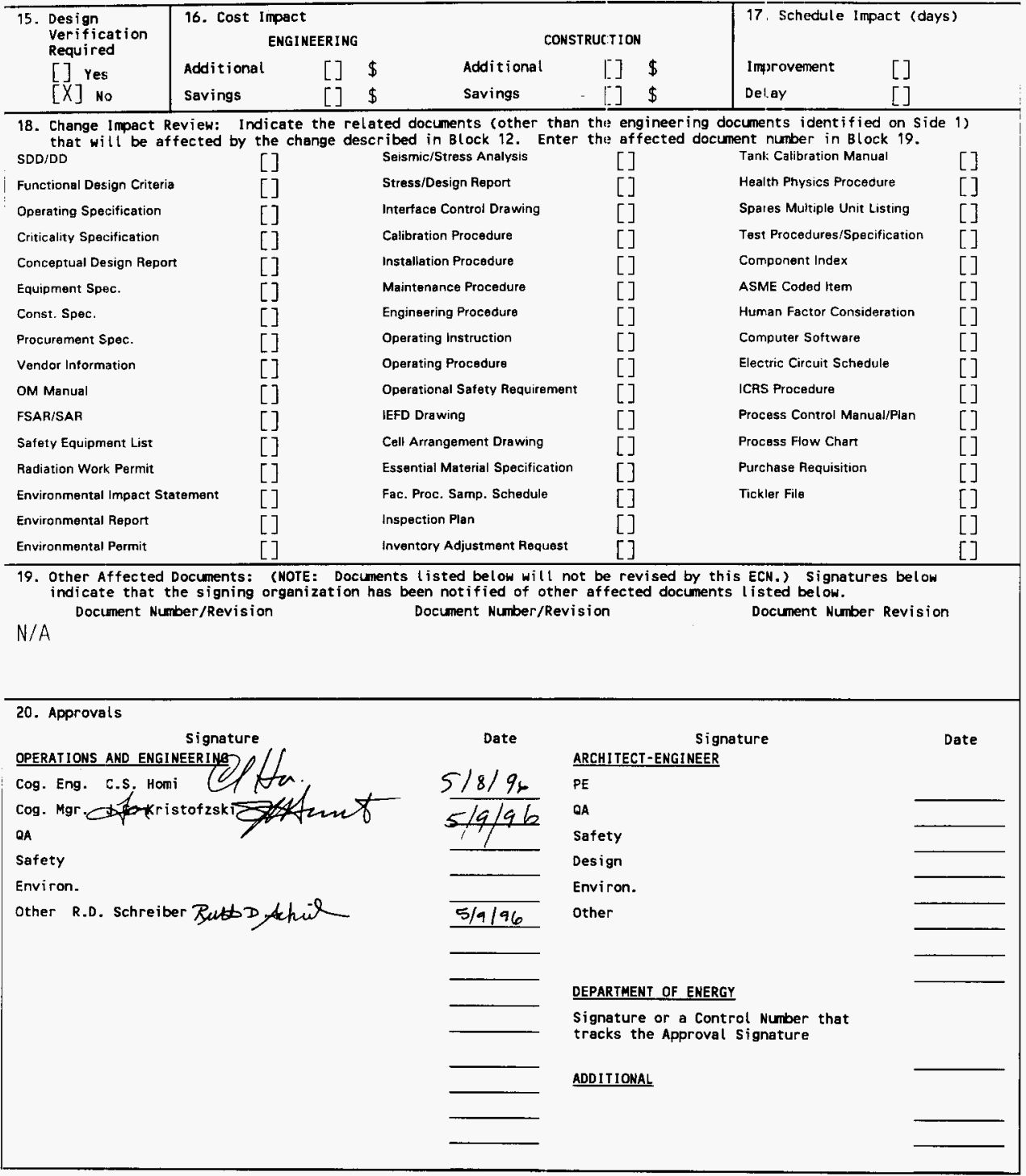




\section{Tank 241-A-104 Tank Characterization Plan}

C. S. Homi

Westinghouse Hanford Company, Richland, WA 99352

U.S. Department of Energy Contract DE-AC06-87RL 10930

EDT/ECN: $\quad$ ECN-631543 UC: 2070

Org Code: 79200 Charge Code: N4G6A

B\&R Code: EW. 3120074 Total Pages: 9

Key Words: Characterization, General Safety Issues, Specific Safety Issues, Information Requirements, Schedule

Abstract: This document is a plan that identifies the information needed to address relevant issues concerning short-term and long-term storage and long-term management of single-shell tank 241-A-104.

TRADEMARK DISCLAIMER. Reference herein to any specific comercial product, process, or service by trade name, trademark, manufacturer, or otherwise, does not necessarily constitute or imply its endorsement, recommendation, or favoring by the United States Govermment or any agency thereof or its contractors or subcontractors.

Printed in the United States of America. To obtain copies of this document, contact: WHC/BCS Document Control Services, P.O. Box 1970, Mailstop H6-08, Richland WA 99352, Phone (509) 372-2420; Fax (509) 376-4989.
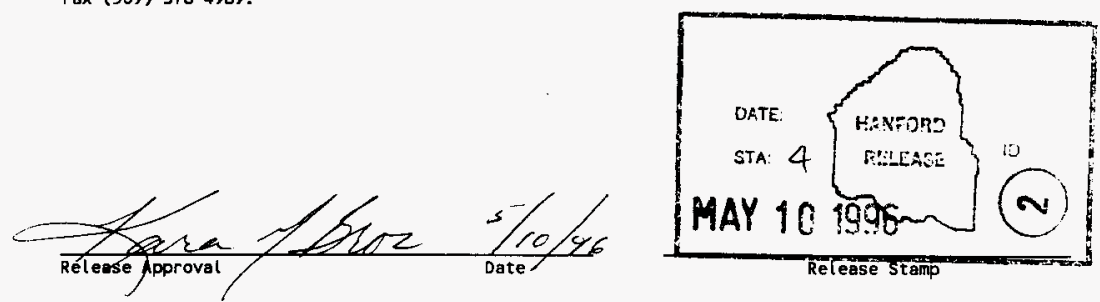

\section{Approved for Public Release}




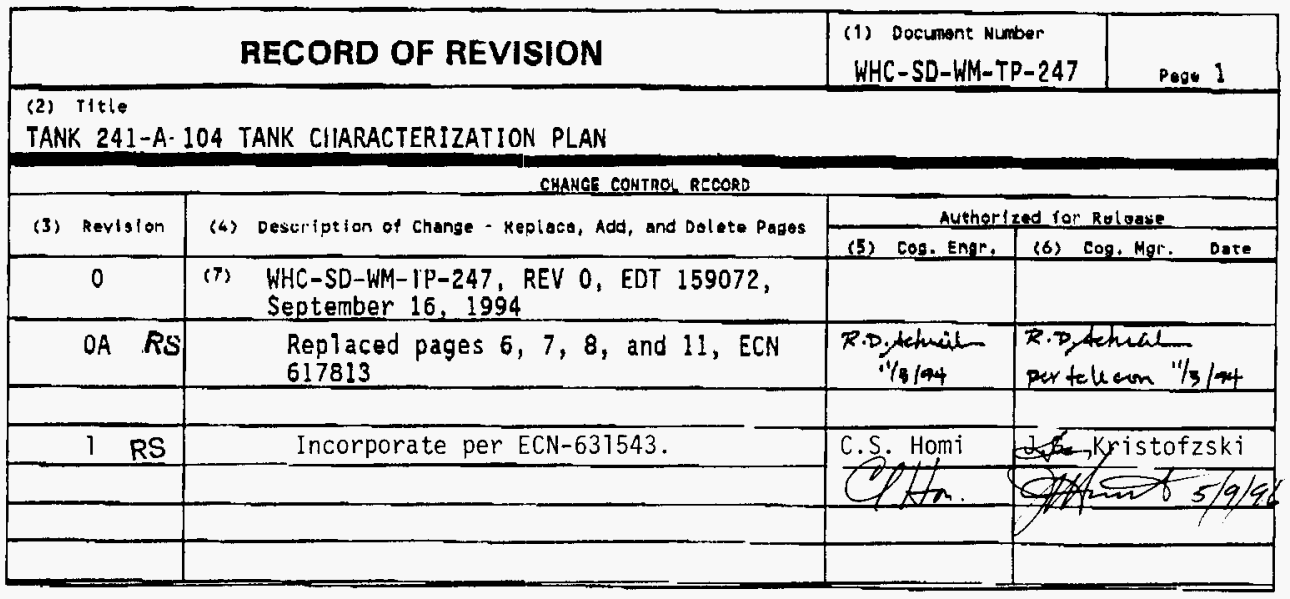


WHC-SD-WM-TP-247

Revision 1

UC-2070

\title{
Tank 241-A-104 \\ Tank Characterization Plan
}

\author{
R. D. Schreiber
}

Westinghouse Hanford Company

Date Published

May 1996

Prepared for the U.S. Department of Energy

Office of Environmental Restoration and

Waste Management

(w) Westinghouse
Hanford Company
Richand, Wastingenon

Management and Operations Contractor for the

U.S. Department of Energy under Contract DE-AC06-87RL10930 
WHC-SD-WM-TP-247, REV 1

TABLE OF CONTENTS

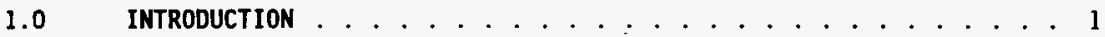

2.0 PROGRAM ELEMENTS REQUIRING INFORMATION FOR TANK 241-A-104 . . . . 2

2.1 GENERAL SAFETY ISSUES ................ 2

2.2 SPECIFIC SAFETY ISSUES .................. . 2

2.2.1 Ferrocyanide ................... 2

2.2.2 Organic...................... 2

2.2.3 High Heat ...................... 2

2.2.4 Flammable Gas.................... 2

2.2 .5 Vapor ...................... 2

2.2 Criticality . . . . . . . . . . . . 3

2.3 CONTINUING OPERATIONS . . . . . . . . . . . . 3

2.3.1 Compatibility/Stabilization ........... 3

2.3.2 Evaporator .................... 3

2.4 DOUbLE-SHELL TANK WASTE ANALYSIS PLAN . . . . . . . . . . . 3

2.5 DISPOSAL . . . . . . . . . . . . . . . . . . 3

2.5.1 Retrieval . . . . . . . . . . . . . . 3

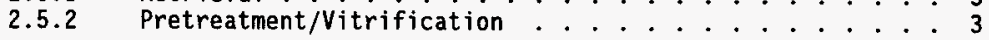

2.6 HISTORICAL MODEL EVALUATION . . . . . . . . . . . . . . 3

3.0 HOW INFORMATION WILL BE OBTAINED . . . . . . . . . . . . . . . . 4

4.0 PRIORITY OF INFORMATION REQUIREMENTS . . . . . . . . . . . . . . . 4

5.0 WHEN INFORMATION WILL BE AVAILABLE ................. 4

6.0 REFERENCES ........................ 5

\section{LIST OF TABLES}

4-1 Integrated DQO Requirements and Priorities . . . . . . . . . 4 


\section{WHC-SD-WM-TP-247, REV 1}

\subsection{INTRODUCTION}

This Tank Characterization Plan (TCP) identifies the information needed to address relevant issues concerning short-term and long-term safe storage and long-term management of single-she11 tank 241-A-104 (A-104). It should be understood that the various needs and issues surrounding tank A-104 are evolving as new information about the tank is uncovered. As a result of this progression, this TCP addresses only the issues that, to this date, have been identified. It is expected that deviations from this plan may occur as additional issues or needs arise which impact the management of tank A-104. As necessary, this TCP will be revised to reflect those changes or deviations. This plan reflects the best information available as of May 1996.

Tank A-104 was constructed between 1954 and 1955 and was put into service in 1957. Initially tank A-104 received waste water from the second quarter of 1957 until the second quarter of 1959. From the third quarter of 1959 until the fourth quarter of 1961, the tank received Plutonium Uranium Extraction (PUREX) high activity neutralized acid waste. From the third quarter of 1960 until the first quarter of 1968, the tank received organic wash waste from the PUREX plant. The tank waste was the self-concentrating or boiling type. Between the second and fourth quarters of 1969, tank A-104 was sluiced for strontium and cesium recovery, and it was declared a spare tank in the fourth quarter of 1969 . The tank contained sluicing water from the fourth quarter of 1969 until the third quarter of 1972. The tank received B plant waste in the fourth quarter of 1972. From the first quarter of 1973 until the third quarter of 1974, the tank received washed PUREX sludge. The tank was sluiced starting in the third quarter of 1974 to reduce the sludge heel and for saltcake storage. The tank was declared an assumed leaker in 1975. Tank A-104 is actively ventilated and was interim stabilized in September 1978 with intrusion prevention completed in 1983 (Anderson 1990; Brevick et a1. 1994).

Tank A-104 currently contains a total waste volume of $106 \mathrm{~kL}$ (28 kgal), which is equivalent to approximately $25 \mathrm{~cm}$ (10 in) of waste as measured from the baseline of the tank (Hanlon 1996).

This tank is not on any watch List.

Near-term sampling and analysis activities are focused on either verifying or changing the Watch List tank status, and identifying any new safety issues. Should any safety issues be identified, additional analysis will occur consistent with the identified issue.

In addition to the resolution of the safety issues, it is intended that all tank waste will be subject to pretreatment and retrieval to prepare for final storage or disposal. Presently, these long-range plans have yet to be fully identified and are, therefore, not included in this document. 


\subsection{PROGRAM ELEMENTS REQUIRING INFORMATION FOR TANK 241-A-104}

This section identifies the various program elements, and identifies which of these programs require characterization data from tank A-104.

\subsection{GENERAL SAFETY ISSUES}

The Tank Safety Screening Data Quality Objective (Dukelow et al. 1995) describes the sampling and analytical requirements that are used to screen waste tanks for unidentified safety issues. Analytical requirements for the safety screening of a tank are energetics, total alpha activity, moisture content, density and flammable gas concentration.

\subsection{SPECIFIC SAFETY ISSUES}

\subsubsection{Ferrocyanide}

This tank is not on the Ferrocyanide Watch List; therefore, no information needs are currently identified for this program element.

\subsubsection{Organic}

This tank is not on the Organic Watch List; therefore, no information needs are currently identified for this program element.

\subsubsection{High Heat}

This tank is not on the High Heat Watch List; therefore, no information needs are currently identified for this program element.

\subsubsection{Flammable Gas}

This tank is not on the Flammable Gas Watch List; therefore, no information needs are currently identified for this program element.

\subsubsection{Vapor}

A11 177 underground tanks must be vapor-sampled for organic solvent screening as per Recommendation 93-5 Implementation P7an (DOE-RL 1996). Some tanks may require additional vapor sampling due to other program needs. These tanks may be classified into four categories: (1) those tanks which are to be rotary mode core sampled (as a consequence of the rotary sampling system exhauster permit requirements); (2) tanks on the Organic or Ferrocyanide Watch Lists; (3) tanks in C farm; and (4) tank 241-BX-104, due to vapor exposure. Information needs must satisfy Data Quality objectives for Tank Hazardous Vapor Safety Screening (Osborne and Buckley 1995), and for rotary mode only, Rotary Core Vapor Sampling Data Quality Objective (Price 1994) and Data Quality Objective for Regulatory Requirements for Hazardous and Radioactive Air Emissions Sampling and Analysis (Mulkey and Markillie 1995) as amended by Status of the Current Understanding of 
the Toxic Air Pollutants (TAPS) and Hanford Tank Farm Vapor Space Characterization; Recommended Path Forward and Justification for Continued RMCS Exhauster Operations (Laws 1996).

\subsubsection{Criticality}

No information separate from that for the general safety issue of tank A-104 are currently identified for this program element. However, if the general safety screening of tank A-104 identifies a potential criticality concern, analyses for fissile materials and neutron sorbers and poisons will be performed as identified in the safety screening data quality objective (DQO).

\subsection{CONTINUING OPERATIONS}

\subsubsection{Compatibility/Stabilization}

This section does not apply to tank A-104.

\subsubsection{Evaporator}

This section does not apply to tank A-104.

\subsection{DOUBLE-SHELL TANK MASTE ANALYSIS PLAN}

This section does not apply because tank A-104 is a single-shell tank.

\subsection{DISPOSAL}

\subsubsection{Retrieval}

Current retrieval needs ( $B 1$ oom and Nguyen 1995) do not call for test samples to be taken from tank A-104.

\subsubsection{Pretreatment/Vitrification}

Tank A-104 has not been identified as a bounding tank for pretreatment/ disposal process development strategy (Kupfer et al. 1995). All tanks were prioritized using the pretreatment strategy in the Tank Waste Characterization Basis (Brown et al. 1995) document and a portion of archive sample material could be used for pretreatment testing if available. The strategy does not require any specific analyses to be done on the samples.

\subsection{HISTORICAL MODEL EVALUATION}

Bounding tanks and data requirements for historical model evaluations are found in Historical Model Evaluation Data Requirements (Simpson and McCain 1995). Tank A-104 has been identified as a primary bounding tank for the AR waste type 
(waste from various washes of sludge in the AR Vault). All single-shell tanks were prioritized in the Tank Waste Characterization Basis (Brown et al. 1995) document using the historical DQO.

\subsection{HOW INFORMATION WILL BE OBTAINED}

The number of samples required to characterize a tank is a function of waste heterogeneity and the desired confidence to make a correct decision. As directed by the safety screening DQO, if inadequate information exists to determine an appropriate number of samples, two vertical profiles will be obtained. These vertical profiles may be obtained using core, auger (for shallow tanks), or grab samples. If analysis of these profiles reveals that additional profiles are necessary to meet data needs, more sample profiles wil1 be requested.

\subsection{PRIORITY OF INFORMATION REQUIREMENTS}

Auger sampling is scheduled for September 1996. Vapor sampling is scheduled for May 1997 (Stanton 1996). Refer to Table 4-1 for the current DQO requirements and planned sampling and analytical requirements.

Table 4-1: Integrated DQO Requirements and Priorities

\begin{tabular}{|l|l|l|l||}
\hline $\begin{array}{l}\text { Sampling } \\
\text { Event }\end{array}$ & \multicolumn{1}{|c|}{ Applicable Issues } & Sampling Requirements & Analytical Requirements \\
\hline $\begin{array}{l}\text { Auger } \\
\text { Sampling }\end{array}$ & $\begin{array}{l}\text {-Safety Screening DQO } \\
\text {-Historical DQO }\end{array}$ & $\begin{array}{l}\text { Auger samples from 2 } \\
\text { risers separated to } \\
\text { the maximum extent } \\
\text { possible } \\
\text { Combustible gas } \\
\text { measurement }\end{array}$ & $\begin{array}{l}\text { Flammability, Energetics, } \\
\text { Moisture, Total alpha } \\
\text { activity, Density, } \\
\text { Anions, Metals, } \\
\text { Radionuclides, TOC }\end{array}$ \\
\hline $\begin{array}{l}\text { Vapor } \\
\text { Sampl ing }\end{array}$ & $\begin{array}{l}\text {-Organic Solvent Layer } \\
\text { 93-5 Vapor Issue } \\
\text {-Hazardous Vapor DQO }\end{array}$ & $\begin{array}{l}\text { Steel canisters, } \\
\text { Triple Sorbent Traps, } \\
\text { Sorbent Trap Systems }\end{array}$ & $\begin{array}{l}\text { Flammable Gas } \\
\text { Organic Vapors } \\
\text { Permanent Gases }\end{array}$ \\
\hline
\end{tabular}

* Consult each applicable DQ0 in force at the time for sampling and analytical requirements.

\subsection{WHEN INFORMATION WILL BE AVAILABLE}

According to Stanton (1996), data are expected to be available from the auger sampling event for tank A-104 in January 1997. The vapor sampling data are expected in July 1997. These times may be altered if the sampling schedule changes. 


\section{WHC-SD-WM-TP-247, REV 1}

\subsection{REFERENCES}

Anderson, J. D., 1990, A History of the 200 Area Tank Farms, WHC-MR-0132, Rev. 0, Westinghouse Hanford Company, Richland, Washington.

Bloom, G. R. and Q. H. Nguyen, 1995, Characterization Data Needs for Development, Design and Operation of Retrieval Equipment Developed Through the Data Quality Objective Process, WHC-SD-WM-DQO-008, Rev. 0, Westinghouse Hanford Company, Richland, Washington.

Brevick, C. H., L. A. Gaddis, and A. C. Walsh, 1994, Supporting Document for Northeast Quadrant Historical Tank Content Estimate Report for A-Tank Farm, WHC-SD-WM-ER-308, Rev. 0, Westinghouse Hanford Company, Richland, Washington.

Brown, T. M., S. J. Eberlein, and T. J. Kunthara, 1995, Tank Waste Characterization Basis, WHC-SD-WM-TA-164, Rev. 1, Westinghouse Hanford Company, Richland, Washington.

DOE--RL, 1996, Recommendation 93-5 Implementation Plan, D0E/RL-94-0001, Rev. 1, U.S. Department of Energy, Richland, Washington.

Dukelow, G. T., J. W. Hunt, H. Babad, and J. E. Meacham, 1995, Tank Safety Screening Data Quality Objective, WHC-SD-WM-SP-004, Rev. 2, Richland, Washington.

Hanion, B.M., 1996, Waste Tank Summary for Month Ending January 31, 1996, WHC-EP-0182-94, Westinghouse Hanford Company, Richland, Washington.

Kupfer, M. J., W. W. Schultz, and J. T. Slankas, 1995, Strategy for Sampling Hanford Site Tank Wastes for Development of Disposal Technology, WHC-SD-WM-TA-154, Rev. 1, Westinghouse Hanford Company, Richland, Washington.

Laws, G. L., 1996, Status of the Current Understanding of the Toxic Air Pollutants (TAPS) and Hanford Tank Farm Vapor Space Characterization; Recommended Path Forward and Justification for Continued RMCS Exhauster Operations, (telephone conference memorandum 01830-96-022, to Distribution, March 8), Westinghouse Hanford Company, Richland, Washington.

Mulkey, C.H., and K. D. Markillie, 1995, Data Quality Objective for Regulatory Requirements for Hazardous and Radioactive Air Emissions Sampling and Analysis, WHC-SD-WM-DQO-021, Rev. 0, Westinghouse Hanford Company, Richland, Washington.

Osborne, J. W., and L. L. Buckley, 1995, Data Quality Objectives for Tank Hazardous Vapor Safety Screening, WHC-SD-WM-DQO-002, Rev. 2, Westinghouse Hanford Company, Richland, Washington. 


\section{WHC-SD-WM-TP-247, REV 1}

Price, D. N., 1994, Rotary Core Vapor Sampling Data Quality Objective, WHC-SD-WM-SP-003, Rev. O, Westinghouse Hanford Company, Richland, Washington.

Simpson, B. C., and D. J. McCain, 1995, Historical Model Evaluation Data Requirements, WHC-SD-WM-DQO-018, Rev. OA, Westinghouse Hanford Company, Richland, Washington.

Stanton, G. A., Baseline Sampling Schedule, Change 96-02 (Internal memo 75610-96-06, to Distribution, Apri1 17), Westinghouse Hanford Company, Richland, Washington. 
DISTRIBUTION SHEET

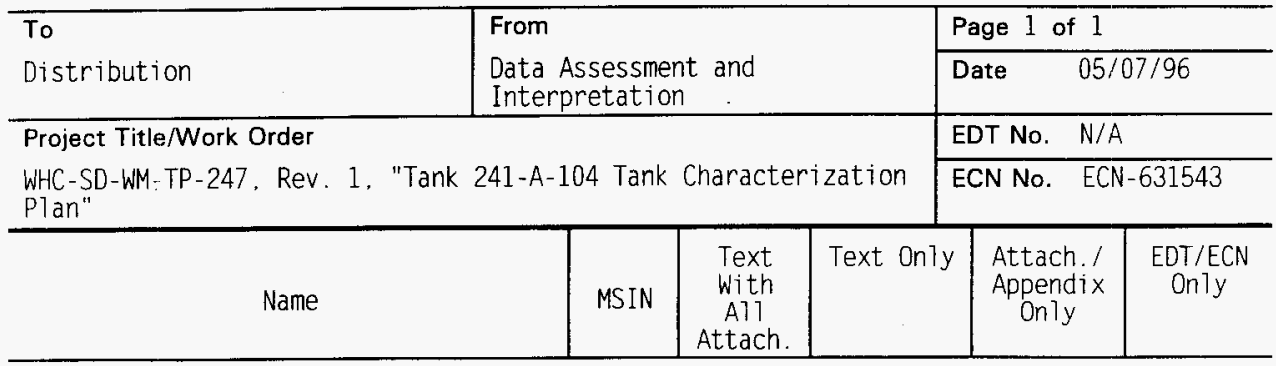

ONSITE

U. S. Department of Energy -

Richland Field Office
W. Liou
N. W. Willis
$57-54 \quad x$
$57-54 \quad x$

Westinghouse Hanford Company

G. D. Forehand

S7-21 $\quad x$

C. S. Homi

R2-12 $\quad x$

R. D. Schreiber

R2 -12

A3-88

Central Files

T.C.R.C.

R2-12

X

$X$

\section{OFFSITE}

U. S. Department of Energy - Headquarters

Office of Environmental Restoration and

Waste Management EM-563

12800 Middlebrook Road

Germantown. MD 20874

J. A. Poppiti 